\title{
An Optimality Analysis of the Phonology of French Loanwords as Manifested in the Eastern Part of Algeria
}

\author{
Sara Kessar (Corresponding author) \\ $\mathrm{PhD}$ Candidate in Linguistics, The University of Jordan \\ Amman, Jordan \\ E-mail: Sarahkessar21@gmail.com \\ Radwan S. Mahadin \\ Department of English Language and Literature, The University of Jordan \\ PO Box 11942, Amman, Jordan
}

Received: January 25, 2020

doi:10.5296/ijl.v12i2.16711
Accepted: February 26, 2020 Published: March 18, 2020

URL: https://doi.org/10.5296/ij1.v12i2.16711

\begin{abstract}
The present study sheds lights on the French loanwords which are integrated in the Algerian Spoken Arabic (ASA), particularly the dialect spoken in the Eastern part. It identifies the phonological processes used to adapt them within an Optimality Theory (OT) framework. A thorough scrutiny of the data indicated that the French loanwords underwent a number of adaptations to fit into the phonological system of the Algerian Arabic. Moreover, the results revealed that this nativization process involves a number of phonological processes, namely unpacking of nasal vowels, nasal place assimilation, vowel deletion, front vowel raising, voicing, devoicing and stopping, in addition to lateral assimilation. The application of optimality framework as to explicate the adaptations of French loanwords has shown that they emanate from a steady conflict between the faithfulness constraints, which condition the preservation of original input forms, and the markedness constraints describing the Algerian Arabic marked phonological system.
\end{abstract}

Keywords: Loanwords, Algerian Spoken Arabic (ASA), Optimality Theory (OT), Phonological processes 


\section{Introduction}

The momentousness of examining loanwords has widely been recognized in the literature. Phonologists have long held an interest in loanword phonology as an area able to shed additional light on the phonotactic constraints of languages (Wornyo, 2016). According to Davis (1993) "the first reason for which loanwords are of interest to phonologists lies in the fact that the way loanwords are produced and heard in the borrowing language is always distinct from how they are produced and heard in the lending language" (p.1). The second reason is that the phonological features of loanwords are unique and this makes them distinct from the recipient language.

Generally speaking, many people in the field tend to correlate loanwords with loanblends and loanshifts. However, Haugen (1950) draw a clear cut between the three types. According to him, as opposed to loanblends which show both "morphemic substitution as well as importation", "loanshifts show morphemic substitution without importation" and loanwords "show morphemic importation without substitution" (p.215). Put it simply, loanblends involve a combination of a native constituent and a foreign copied part, as in the English word 'plum pie' which originates from the Pennsylvania German word [blaUməpal], whrein there is a morphem importation [pal] and at the same time a morpheme substitution [blaUmə] for plum (Lucas, 1995). In loanshifts there is no morpheme importation as illustrated by the French word 'gratte-ciel' from the English word 'skyscraper', but the meaning is copied from the donar language (Lucas, 1995). Accordingly, loanshift is the umbrella term for both semantic borrowing and loan translation. Loanwords, on the other hand, show no morphemic substitution hence both the meaning and the form are copied (Hamdi, 2017).

Rose (1999) claimed that when loanwords enter a language they often "violate the phonological well formedness constraints of the borrowing language" (p.1) as they contain a different structure. In order to comply with these constraints, adjustment of the ill formed structures is required. Uffman (2001) added that loanwords endure modifications because preliminary conditions on surface syllable structure impose them to change. For this reason, earlier proposed frameworks which were mainly rule-based fail to account for how these borrowed words are nativized. Golston and Yang (2001) asserted that "rule-based analysis of loanwords results in rules that are neither rules of the donor language nor of the native language" (p.1). They proposed that the Universal Grammar rules appear to apply when the loanwords undergo a phonological adaptation. However, Wornyo (2016) claimed that this suggestion may not be generalizable because loanwords adaptation varies from one language to another depending on the phonotactic constraints and the phonemic inventory of the borrowing language. Accordingly, an extensive line of research opted for constraint based framework to overcome the limitations of previous theories.

Kenstowicz (2012) argued that with the advent of constraint-based frameworks like the Optimality Theory (OT), the study of loanwords from a phonological perspective has received a renewed interest. According to Kenstowicz (2012), OT theory helps explaining loanwords adaptation through the conflict between the faithfulness constraints which necessitate the segments to rest faithfull to the lending language, and the markedness 
constraints that impose adaptation to the loanwords so as to fit the phonotactic constraints of the recipient language.

Prince and Smolensky introduced the optimality theory (OT) in 1993 as a model for linguistic analysis. MaCarthy (2002) states that the essence of optimality theory is the supposal that linguistic generalizations should be described via constraints which are ranked based on their importance. Accordingly, constraints are universal but their ranking is language specific. That is to say they are violable and can be mirrored via two facets: faithfulness constraints and markedness constraints. The former ensure that output representations (surface) resemble input representation (underlying) while the latter require the output to be the same as the input. The basics of optimality are not restricted to constraints, but rather as McCarthy (2007) claimed involves evaluator (EVAL) and generator (GEN). He contends that GEN is capable of generating an infinite number of outputs and the EVAL function is to select the most harmonious candidate that violates the least ranked constraints. At this juncture, it is worth claiming that loanwords in Algerian spoken Arabic would be better explicated under the umbrella of optimality framework.

\section{Previous Studies}

The study of loanwords in an array of languages was the core of numerous studies. For example, Yip (1993) studied the English loanwords in Cantonese Chinese variety using the optimality theoretic ranking of constraints. The researcher pointed out that the complex structure of the English syllable requires the Cantonese speakers to posit adjustments so as to match the constraints of the Cantonese syllable structure. In the same vein, Rungruang (2007) analysed the way English loanwords are integrated into the Thai phonological system within the framework of Optimality Theory. Specifically, the focus was on laryngeal features, medial consonants, liquid alternation and onset/coda simplification. The results revealed that no repair strategy was found when the sounds of the borrowed word are the same in Thai language. However, to deal with non-correspondence amidst the two languages, Thai speakers subrogated unlicensed consonants by either auditory similar segments or segments that share the same natural class. Accordingly, a number of processes were identified: insertion, deletion, substitution and fusion.

Hashemi and Kambuziya (2014) examined the phonological adaptation of Arabic loanwords in Persian with the focus on consonants. They gathered about 700 Arabic loanwords from Persian dictionnaries which constituted the main data of the study. The results of the optimality analysis revealed that the places of articulation that are inactive articulators in Persian language as; phrangeal, interdental and biilibial glide were replaced by the closest consonants in terms of palce of articulation. Thus the Arabic loanwords were adapted to fit the phonemic inventory of the Persian language. In almost a similar study, Alqahtani (2018) found that Arabic complex clusters that seem to violate the sonority sequencing of the Salzevaril Persian was the main motive for epenthesis and metathesis. Accordingly, the loanwords were adapted to match the syllable structure of the borrowing language.

Although an extensive number of pioneering studies have targeted laonwords in different languages, still very meagre inquiry was devoted to the analysis of foreign loanwords in 
Arabic dialects. The first seminal study was conducted by Butros (1963) wherein he collected 1230 common English loanwords that were in use in Jordan and Palestine. His focus lies mainly on revealing the effect of those foreign words on Arabic dialects from a number of perspectives; phonological, morphological and semantic. Following similar lines of inquiry Jarrah (2013) examined English loanwords in Madin Hijazi Arabic within an optimality framework. The results indicated that adaptation of loanwords involved a number of phonological processes such as voicing epenthesis, vowel change and resyllabification in order to maintain the required phonological structures.

In another study, Aloufi (2016) provided a deep analysis of English loanwords in Urban Hijazi dialect. To satisfy the aim of the study, the reseracher opted for two theoretical frameworks: the Theory of Constraints and Repair Strategies Loanword Model (TCRSLM) proposed by Paradis and LaCharite (1997) and Optimality Theory (OT). The analysis of the different phonological processes revealed that OT theory accounts better for the analysis of loanwords though the TCRSL model relies on autosegmental analysis.

As far as the Algerian context is concerned, reviewing the literature revealed that studies on French loanwords from a phonological perspective have not received ample attention within either the framework of OT or another theory. The only adequate study is that of Benali (2018), who dealt with stress and intonation patterns of loanwords in Algerian Arabic. The findings show that speakers tend to transfer the stress and intonation pattern of Algerian Arabic to the French loanwords.

Reviewing the literature revealed that French loanwords in Algerian spoken Arabic require further studies particularly from a phonological perspective. Therefore, the present study aims at adding to the growing literature by filling this gap. More specifically, this research seeks to analyze the French loanwords integrated in the Algerian Arabic, particularly in the Eastern part of Algeria, and uncovering the phonological processes used to adapt them within an Optimality Theory Framework.

\subsection{Syllable Structure of the Algerian Spoken Arabic}

The Algerian spoken Arabic belongs to the Maghrebi Arabic language spoken in North Africa. Generally speaking, Maghrebi Arabic dialects share a number of phonological and morphological features that distinct them from other varieties; Peninsular Arabic, Levantine and Egyptian. Syllable structure is one of the most pertinent differences amid Arabic vernaculars. A number of typological studies (Kiparsky, 2003; Hamdi, Ghazali \& Defradas, 2005) have pointed out that Middle East dialects exhibit a tendency towards long vowels and simple syllables (CV, CVC, CVVC). North African dialects, on the other hands, are characterized by short vowels and complex syllables such as: CCVC, CCVCC. This goes in the same line with the syllable types identified by Chebchoub (1985, p. 240) which exist in the Algerian dialect: 


\begin{tabular}{|c|c|c|}
\hline 1. $\mathrm{CV}$ & /dari/ & "my house" \\
\hline 2. $\mathrm{CVC}$ & /qulti/ & "you said" \\
\hline 3. $\mathrm{CV}: \mathrm{C}$ & /qafhum/ & "their suit" \\
\hline 4. $\mathrm{CVCC}$ & /Selk/ & "chewing gum" \\
\hline 5. CCV & $/ \mathrm{kla} /$ & "he ate" \\
\hline 6. $\mathrm{CCVC}$ & /sbər/ & "he was patient" \\
\hline 7. CCVCC & /sbərt/ & "I was patient" \\
\hline 8. $\mathrm{CCCV}$ & $\ln \int \mathrm{ra} /$ & "it was bought" \\
\hline 9. $\mathrm{CCCVC}$ & /nbGat/ & "it was sent" \\
\hline 10. CCCVC & /nfra:w/ & "they were bought" \\
\hline 11. CCCVCC & / ftrəndz/ & "chess" \\
\hline
\end{tabular}

The foregoing types clearly show that the ASA is a C-dialect, in that it allows a sequence of consonant clusters in both the onset and the coda. Chebchoub (1985) stated that the following syllable structures: $\mathrm{CV}, \mathrm{CVC}, \mathrm{CV}: \mathrm{C}$, and $\mathrm{CCV}$ can occur freely in word-initial, medial or final positions. The remaining syllable types -except for the last one- can occur only in word-initial position and in isolation.

\section{Methodology}

The central informant of the data is first the author who is a native speaker of the spoken variety under scrutiny: Eastern part of Algeria. However, this also reinforced by consulting several other Algerian Ph.D speakers from the Eastern regions for the sake of providing more examples. Besides, the researcher relied on Chebchoub's Doctoral dissertation (1985) and a number of Facebook posts that were highly propitious. For the French words transcription, two main dictionaries were used; La Rousse and Concise Oxford Hachette French Dictionary.

\section{Results and Discussion}

\subsection{Unpacking of Nasal Vowels}

Phonetically speaking, Arabic vowel inventory lacks nasal vowels and the same applies to colloquial ialects in Arabic as pointed out by (Chebchoub, 1985; Kenstowicz \& Louriz, 2009). Consequently, the nasal vowels contained within loanwords either its nasality feature is

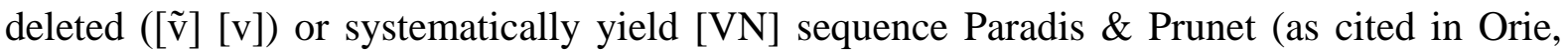
2014 , p.1). The results of the present study have shown that when French nasal vowels are introduced in the Algerian dialect they get repaired by being decomposed rather than deleted. Data bearing on this situation are presented (1): 
(1) French

[bãk]

[kastว̃]

[vakãs]

[ $\left.\int i f \tilde{]}\right]$

[аsувãs]
Algerian

/banka/

/karton/

/fakans/

/Jifun/

/asirons/
Gloss

'bank'

'cardboard'

'vacancy'

'frippery clothes'

'assurance'

An optimality description of this vowel breaking requires bringing three constraints into prominence. Basically, the markedness constraint Unpack Nasal V: "the decomposition of a

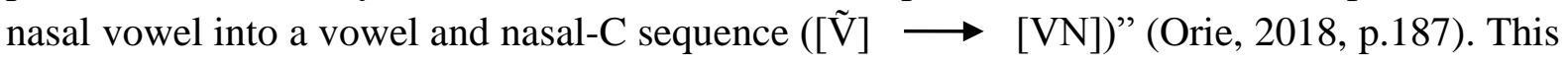
constraint is high ranked since the nasal vowels were decomposed; hence it dominates the faithfulness constraint Integrity which prohibits unpacking. The latter is also predominated by MAX-Ṽ-IO: input nasal vowels must have output correspondent; no nasal feature deletion. The constraints hierarchy together with Table 1 elucidate the interaction betwixt markedness and faithfulness constraints in selecting the optimal output for /kaRtõ/:

Table 1. The optimal output for /kantõ/

\begin{tabular}{|c|c|c|c|}
\hline /kantว̃/ 'cardboard' & Unpack Nasal V & 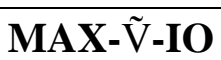 & Integrity \\
\hline a.kart̃̃ & $* !$ & & \\
\hline b.Karto & & $* !$ & \\
\hline c. & & & $*$ \\
\hline
\end{tabular}

Unpack Nasal V >> Max- $-\tilde{V}-$ IO >> Integrity.

Among the candidates provided in Tableau 1, candidate (a) is prone to lose the competition as it averts a fatal violation of the top ranked constraint Unpack Nasal V. Candidate (b) generates a wrong output and this represents the sole reason for its elimination. Accordingly, candidate (c) (pointed at by the index) wins the race by violating only the least ranked constraint Integrity.

\subsection{Nasal Place Assimilation}

The tendency for decomposing French nasal vowels in Algerian dialect creates a fertile phonetic environment for nasal place assimilation. This process occurs when a nasal phoneme assimilates the place feature of a neighbouring sound. The following examples elucidate the point:

(3) French

[тва̃sров]

[bãk]

[lãp]

[厅а̃bь
Algerian

/tronspor/

/banka/

/lomba /

/ Jombra /
Gloss

'transport'

'bank'

'ampoule'

'room' 
As it is plainly displayed in (3), all nasal vowels undergo unpacking into a sequence of $\mathrm{V}+\mathrm{N}$. Therefore, the faithfulness constraint Integrity is violated to meet the requirement of the markedness constraint Unpack Nasal. Subsequently, the nasal [n] gets assigned the same place feature of the following obstruent consonants (bilibial, stop, fricative). The nasal place assimilation satisfies the high ranked markedness constraint Nasal Place which states that nasals must get assigned the same place feature of the following obstruent MaCarthy (as cited in Kang, 1989); however, this done at the expense of the faithfulness constraint IDENT- IO (place). The constraint ranking accounts for these phonological processes:

Table 2. The optimal output for / $/$ ãbs/

\begin{tabular}{|c|c|c|c|c|}
\hline 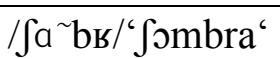 & Unpack Nasal & Nasal Place & IDET-IO (place) & Integrity \\
\hline a. ब्जambra & & & $*$ & $*$ \\
\hline 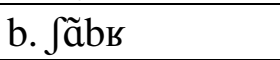 & $* !$ & & & \\
\hline c. Janbra & & $* !$ & & $*$ \\
\hline
\end{tabular}

Unpack Nasal >> Nasal ${ }^{\text {Place }}>>$ IDET-IO (place), Integrity.

Note that in Tableau 2 candidate (a) is the winning one because it incurs the least costly violation of IDENT-IO (place) and Integrity constraints. Accordingly, both candidates (b) and (c) fail to survive as they fatally violate the top ranked constraints Unpack Nasal and Nasal ${ }^{\text {Place }}$.

\subsection{Front Vowel Raising}

The Arabic vowel inventory is characterized by a limited number of vowels as opposed to the European languages. This vowel system has three short and three long vowels /a, i, u, a:, i:, u:/ (Mahadin, 1982). The Algerian dialect kept almost the SA vowels ([o] and [æ] are just variants of $[\mathrm{u}]$ and [a], respectively) with the addition of the short central vowel [ə] that characterizes the Maghreb dialects (Lahrouchi, 2018). The point is that besides the absence of French nasal vowels, the Algerian vocalic system lacks the open-mid front unrounded vowel $[\varepsilon]$. Accordingly, this vowel is adapted via raising it to the high vowel [i]. The following data are a case in point:

\begin{tabular}{|c|c|c|}
\hline (5) French & Algerian & Gloss \\
\hline [konckte] & /konikti/ & 'connected' \\
\hline [diser $]$ & /disir/ & 'dessert' \\
\hline [geb] & /girra/ & 'war' \\
\hline [betsav] & /bitraf/ & 'beet' \\
\hline [fвєz] & /friza/ & 'strawberry' \\
\hline
\end{tabular}

This adaptation indicates the ranking of the markedness constraint *MID [-ATR] which prohibits mid lax vowels (Miglio, 2005) over the faithfulness constraint IDENT (Height) (Miglio, 2005). Moreover, the markedness constraint *Complex Onset CCC (Al-Mohanna, as cited in Benyoucef \& Mahadin, 2013) that allows no more than two consonants in onset 
position, is used to avoid vowel deletion. The following constraint ranking along with Table 3 illustrates this state of mind:

Table 3. The optimal output for /betвav/

\begin{tabular}{lccc}
\hline /betвav/ 'beet' & $*$ MID[-ATR] & $*$ Complex ONS (CCC) & IDENT(Height) \\
\hline a. betвav & $* !$ & & \\
\hline b. btвav & & $* !$ & $*$ \\
\hline c. bitsaf & & & \\
\hline
\end{tabular}

*MID [-ATR] $>>$ *Complex ONS C(CC) >> IDENT(Height).

The overall ranking in Table 3 plainly displays that the competition between candidates (a), (b) and (c) is decided in favour of candidate (c), since it violates the low-ranked constraint IDENT (Height). (a) is eliminated because it violates the top ranked constraint *MID [-ATR] by preserving the mid vowel $[\varepsilon]$. Likewise, (b) includes the impermissible tri-consonantal onset, thus it averts a fatal violation of the second higher constraint *Complex ONS (CCC).

\subsection{Voicing}

Many studies have demonstrated that when a loanword includes unvoiced bilabial stop [p] it is usually reproduced in Arabic dialects as [b] (Sayahi, 2005; Al-Saqqaf, 2006). This confirms the claim held by Paradis (1996) that when segment is not preserved, its closest phoneme would be adapted. The following examples illustrate how the Algerian dialect substitutes the [p] sound with its closest counterpart [b].

(7) French

[potazi]

[post]

[polis]

[pomad]

[pisin]
Algerian

/botazi/

/bosta/

/bulis/

/bomad/

/bisin/
Gloss

'kitchen garden'

'post office'

'police'

'cream'

'swimming pool'

According to the examples in (7) three constraints are in conflict. The first is the markedness constraint *P [-voice] which prohibits voiceless bilabial stop (Baayen, 2003). The second markedness constraint is Onset which disallows onsetless syllables. The last constraint is the faithfulness constraint IDENT-IO [Voice] that does not permit changes. Obviously, these constraints are in conflict. It follows that the markedness constraint ${ }^{*} \mathrm{P}$ [-voice] is higher ranked in ASAand it is satisfied by violating the least ranked faithfulness constraint IDENT-IO [Voice]. This latter is also dominated by ONSET which militates against onsetless syllable, hence deleting the [p] sound is not allowed. 


\section{Macrothink}

Table 4. The optimal output for /pomade/

\begin{tabular}{lccc}
\hline /pomad/ 'cream' & $*$ P[-Voice] & ONSET & IDENT-IO[Voice] \\
\hline a. pomad & $* !$ & & \\
\hline b. romad bomad & & $*$ \\
\hline c. omad & & $* !$ & \\
\hline
\end{tabular}

*P [-voice] $>>$ Onset $\gg>$ IDENT-IO [Voice].

According to tableau 4, candidate (a) is excluded as it violates the higher ranked constraint *P [-voice] by preserving the voiceless bilabial [p] sound. Likewise, candidate (c) is ruled out since it leads to create an illicit syllable (onsetless syllable). Hence, (b) wines the competition as it violates only the lower ranked constraint IDENT-IO [Voice].

\subsection{Devoicing and Stopping ([v] Sound)}

Needless to say, Arabic consonantal inventory lacks the voiced labiodental [v]. Therefore, as claimed by Hafez (1996) in his seminal article, Phonological and Morphological Integration of Loanwords into Egyptian Arabic, whenever a loanword includes a [v] sound "it is often replaced by [f] (its voiceless counterpart) or by [b] (its plosive counterpart)" (p. 5). The following examples demonstrate the various attested adaptations of [v] in ALG dialect:

(9) French

[betrav]

[valiz]

[sova3]

[savõ]

[scRvi]

[savat]

[seRvjet]
Algerian

/bitraf/

/faliza/

/sofaz/

/sabon/

/sirbi/

/sabat/

/sarbita/
Gloss

'bleach'

'suitcase'

'savage'

'soap'

'serve'

'shoe'

'napkin'

Essentially, the devoicing of the French labiodental [v] can be explained within the optimality framework through the interaction between the markedness constraints * F [+/-voice] which prohibits voiced labiodental fricatives (Baayen, 2003) and the faithfulness constraint IDENT-IO [Voice]. Given the fact that the markedness constraint *F [+/-voice] cannot be violated in the phonology of the ASA, it must be ranked higher than the faithfulness constraint IDENT-IO [Voice] as it is illustrated in the hierarchy:

Table 5. The optimal output for /sovaz/

\begin{tabular}{lcc}
\hline /sovaz/ 'savage' & $* \mathbf{F}$ [+voice] & IDENT-IO[+/-Voice] \\
\hline a. sova3 & $* !$ & \\
\hline b. ${ }^{\text {sofa3 }}$ & & $*$ \\
\hline
\end{tabular}

*F [+voice] >> IDENT-IO [+/-Voice] 


\section{I Macrothink}

International Journal of Linguistics

ISSN 1948-5425

2020, Vol. 12, No. 2

The two candidates /sovaz/ and /sofaz/ display options for the adaptation of [v]. The first candidate is not the optimal one since it violates the higher ranked markedness constraint $* \mathrm{~F}$ [+voice]. Candidate (b) is the most harmonious one as it incurs the least costly violation of the constraint IDENT-IO[+/-Voice].

As for the adaptation of $([\mathrm{v}]>[\mathrm{b}])$ it can be explained with reference to the competition between the markedness constraint $* \mathrm{~F}$ [+voice] and the faithfulness constraint IDENT-IO[+/-continuant] as it is shown in table 6:

Table 6. The optimal output for /savat/

\begin{tabular}{lcc}
\hline /savat/ 'sabat" & $* \mathbf{F}[+$ voice] & IDENT-IO[+/-continuant] \\
\hline a. savat & $* !$ & \\
\hline b. sabat & & $*$ \\
\hline
\end{tabular}

$* \mathrm{~F}[+$ voice $] \gg$ IDENT-IO [+/-continuant]

Tableau (6) indicates that candidate (b) is the optimal candidate as it is the most harmonious with constraint hierarchy, violating only the lower ranked IDENT-IO[+/-continuant]. Candidate (a) is excluded as it violates $* \mathrm{~F}$ [+voice] by preserving the /v/ sound.

However, there is one problem with these tableaux. The ranking can only account for a single adaptation alone, while others are not considered. That is to say, the variability of the adaptation of the labiodentals [v] are not accounted for. Thus, (Aloufi) 2016 suggests a proper solution for this matter by re-ranking the same constraints used before, and instead of evaluating each adaptation separately, they just need to go under one evaluation.

The new proposed ranking that can effectively account for this variation requires the markedness constraint $* \mathrm{~F}$ [+voice] above all the other faithfulness constraints. Furthermore, these faithfulness constraints should be non-dominant and equally ranked. This will satisfy the need to have more than one optimal output by allowing more candidates to be optimal. In sum, optimality framework enables us to predict the occurrence of all of these possibilities. The constraint hierarchy for the possible adaptations of $[\mathrm{v}]$ sound is indicated below:

Table 7. The different optimal outputs for $[\mathrm{v}]$ sound

\begin{tabular}{llll}
\hline$[\mathrm{v}]$ & $* \mathrm{~F}$ [+voice] & IDENT-IO[+/-continuant] & IDENT-IO[+/-Voice] \\
\hline a. $\mathrm{v}$ & $* !$ & \\
\hline b. $\mathrm{f}$ & & $*$ \\
\hline c. $\mathrm{b}$ & $*$ & \\
\hline
\end{tabular}

*F [+voice] >> IDENT-IO[+/-continuant], IDENT-IO[+/-Voice].

Given the fact that these constraints are ranked equally might allow more than harmonious outputs. As it can be noted from tableau (7) candidates (b) and (c) are the winning ones as they violate only the lower ranked constraints. 


\subsection{Vowel Deletion}

It goes without saying that syllable structure varies appreciably from one language to another. Unlike the French language wherein the onset is an optional element (Kurdi, 2016), the onset node is obligatory in standard and colloquial Arabic i.e., onsetless syllable is not permitted (Louriz, 2004; AlAmro, 2015). Thus, when an onsetless word enters a language that prohibits such pattern, it is either deleted or a consonant is inserted (MaCharthy, 2008). The following examples in (13) clearly display how the ASA deals with onsetless syllable.

(13) French

[ipopotam]

[ама̃sœu]

[Ekzema]

[етэьазі]

[otobys]
Algerian

/popotam/

/sænsur/

/gzima/

/morazi/

/tobis/
Gloss

$$
\begin{aligned}
& \text { 'hippo' } \\
& \text { 'elevator' } \\
& \text { 'aczema' } \\
& \text { 'haemorrhage' } \\
& \text { 'bus' }
\end{aligned}
$$

Seemingly, the onsetless syllables did not surface in the Algerian dialect grammar. Rather, vowel epenthesis is employed so as to militate against an initial VC syllable. An optimality description of this process requires the domination of the markedness constraint ONSET (a syllable must have an onset) over the faithfulness constraint MAX-V-IO, which necessitates vowel input segments to have output correspondents (no deletion). Additionally, since no epenthesis takes place this entails also the outranking of DEP-IO (no insertion) over MAX-V-IO. The following constraint hierarchy together with Table 8 account for the foregoing interaction:

Table 8. The optimal output for /ipopotam/

\begin{tabular}{llll}
\hline lipopotam/ 'hippo' & ONSET & DEP-IO & MAX-IO \\
\hline a. ${ }^{\text {bopotam }}$ & & & $*$ \\
\hline b. ipopotam & $* !$ & & \\
\hline c. nipopotam & & $* !$ & \\
\hline
\end{tabular}

\section{ONSET > DEP-IO > MAX-V-IO.}

Among the candidates proposed in Tableau 8, candidate (a) is the most harmonious one because it incurs the least costly violation of the constraint MAX-IO. Candidate (b) is eliminated from consideration because it violates the top ranked constraint Onset. Likewise, candidate (c) generates a wrong output by violating the second higher constraint DEP-IO, hence it loses the competition.

\subsection{Lateral Assimilation}

One of the underlying assumptions in the present piece of research is that Standard Arabic tends to be the reference for the morphophonemic adaptation of French loanwords. Additional support for this claim comes from prefixation of the Arabic definite article /?il/ to 
the French loanwords. In Standard Arabic the lateral [1] undergoes full assimilation when followed by solar consonants (coronal segments), but no assimilation occurs when followed by moon consonants, i.e. non-coronal (Mangiro, 2016). Accordingly, the same rule seems to apply for the French loanwords:

(14) French

$$
\text { [?il+ nilõ] }
$$

[?il+ воbinje]

[?il+ dosje]

[?il+ limonad]

[?il+ mãda]

[?il+ gato]
Algerian

/Pinnilo /

/Pirrobini /

/Piddosi/

/Pillimonad/

/Pilmanda/

/Pilgato/

Gloss
'nylon'
'faucet'
'file'
'lemonade'
'postcard'
'cake'

It should be intuitively obvious that the lateral [1] undergoes a total assimilation only when followed by a coronal consonant as in /Pinnilo/. In optimality terms, this morphophonemic adaptation indicates the outranking of the markedness constraint [LAT COR] Share (F) proposed by MaCarthy (as cited in, Btoosh 2019), which states that across a morpheme boundary, [1] and the following coronal consonant should be assigned the same token features. Hence, the faithfulness constraint IDENT-IO (F) is undominated. Alternatively, the ASA may insert a vowel to avoid such a sequence of LAT-COR, but this repair mechanism would generate a wrong output / Pilenilo /. Consequently, the least costly repair strategy the dialect opts for lies in assimilating the two segments. A synopsis of the above discussion is encapsulated in the following constraints ranking and illustrated in Table 9.

Table 9. The optimal output for /nilõ/

\begin{tabular}{llll}
\hline$/$ Pil+nilõ/ 'nylon ' & [LAT-COR] Share (F) & DEP-IO & IDENT-IO (F) \\
\hline a. Pilnilo & $* !$ & & \\
\hline b. Pilenilo & & $* !$ & \\
\hline c. Pinnilo & & $*$ \\
\hline
\end{tabular}

[LAT-COR] share $(\mathrm{F})$ > D DEP-IO > IDENT-IO (F).

Tableau 9 clearly indicates that candidate (a) is mercilessly eliminated from consideration as it incurs fatal violation of the highly ranked markedness constraints [LAT-COR] share (F). Likewise, (b) is excluded because it violated the faithfulness constraint DEP-IO by inserting a new segment. This is the reason why (c) is chosen as the most harmonic candidate in the sense that it violates only the lowest ranked IDENT-IO (F).

\section{Conclusion}

Immersion in this piece of research unveiled that the French loanwords underwent a number of phonological processes to conform to the phonology of the Algerian Spoken Arabic, namely: unpacking of nasal vowels, nasal place assimilation, vowel deletion, front vowel 
raising, voicing, devoicing, stopping and lateral assimilation. These processes were attributed to the phonemic inventory and phonological constraints of the Algerian Spoken Arabic which differ from its French counterpart. To put it in optimality terms, the high ranking of some markedness constraints in the dialect under scrutiny were used to straightforwardly account for the adaptation of the French loanwords.

More specifically, Unpack Nasal V, *MID[-ATR], [LAT-COR] share (F), Onset, *F [+voice], and ${ }^{*} \mathrm{P}$ [-voice] are highly ranked in the ASA. Furthermore, the possibility of having different optimal outputs for the sound [v] was explained as the result of the equal ranking of the faithfulness constraints IDENT-IO[+/-continuant] and IDENT-IO[+/-Voice] in the grammar of this dialect. Accordingly, the role of OT in accounting for loanwords adaptation cannot be underemphasized. Hopefully, the study at hand will pave the way for future studies which can identify more phonological processes that result from the interaction between the ASA and other languages as the Spanish and Turkish, taking into account the fact that the Algerian Spoken Arabic is a mixture of various languages (Bekada and Hamane, 2019)

\section{References}

AlAmro, M. (2015). Syllabification in Najdi Arabic: A constraint based analysis. Arab World English Journal (AWEJ), 6(4), 373-388. https://doi.org/10.2139/ssrn.2847466

Aloufi, A. (2016). The phonology of English loanwords in UHA. Unpublished Ph.D. Dissertation, University of Sussex, England.

Alqahtani, M. (2018). Phonological adaptation of Arabic loanwords in Sabzevari Persian: Metathesis and vowel epenthesis. Linguistics and Literature Studies, 6(4), 188-195. https://doi.org/10.13189/1ls.2018.060405

Al-Saqqaf, A. (2006). The linguistics of loanwords in Hadrami Arabic. International Journal of Bilingual Education and Bilingualism, 9(1), 75-93. https://doi.org/10.1080/13670050608668631

Bekada, H, A., \& Hamane, S. (2019). Mixing Languages in the Spoken Discourse of the Algerian Radio Broadcasters: a Strategy for an Effective Communication. The Eurasia Proceedings of Educational \& Social Sciences (EPESS), 13, 72-80.

Benali, I. (2018). Loanwords stress and intonation in Algerian Arabic. Conference Proceedings of 8th Tutorial and Research Workshop on Experimental Linguistics, Heraklion, Crete, Greece. https://doi.org/10.36505/ExLing-2017/08/0004/000306

Benyoucef, R., \& Mahadin, R. (2013). Phonological processes in Algerian Arabic as spoken in Mostaganem: An optimality perspective. Research on Humanities and Social Sciences, 3(14), 85-100.

Butros, A. (1963). English Loanwords in the colloquial Arabic of Palestine (1917-1948) and Jordan (1948-1962). Unpublished Ph. D. Dissertation, Columbia University, US.

Chebchoub, Z. (1985). A socioinguistic study of the use of Arabic and French in Algiers. Unpublished master's Thesis, Edinburgh University, UK.

Chouaou, H., \& Boukhatem, A. (2015). Adaptation of borrowed words from French into Algerian dialect: Case study of Tlemcen speech community. Unpublished MA Thesis, University of Tlemcen, Tlemcen, Algeria. 


\section{Macrothink}

International Journal of Linguistics

ISSN 1948-5425

2020, Vol. 12, No. 2

Davis, S. (1993). Loanwords, phonological treatment: The encyclopedia of language and linguistics. Oxford, UK: Pegamon Press.

Hamdi, R., Ghazali, S., \& Defradas, M. (2005, September 4-8). Syllable structure in spoken Arabic: A comparative investigation. Paper presnented at the 9th European Conference on Speech Communication and Technology, Lisbon, Portugal.

Hamdi, S. (2017). Lexical Borrowing in Arabic and the Role of Orthography. International Journal of Language and Linguistics, 4(2), 17-28.

Hashemi, E. S., \& Kambuziya, A. K. (2014). Phonological adaptation of Arabic loan words in Persian: Consonants. International Journal of Humanities and Social Science, 6(1), 225-236.

Haugen, E. (1950). The analysis of linguistic borrowing. Language, 26(2), 210-231. https://doi.org/10.2307/410058

Jarrah, A. (2013). English loanwords spoken by Madinah Hijazi Arabic speakers. Arab World English Journal AWEJ Special Issue on Translation, 2, 67-85.

Kenstowicz, M. J. (2012). On loanword phonology. Catalan Journal of Linguistics, 11, 7-11. https://doi.org/10.5565/rev/catj1.7

Kenstowicz, M. J., \& Louriz, N. (2009). Reverse engineering: Emphatic consonants and the adaptation of vowels in French loanwords into Moroccan Arabic. Brill's Annual of Afroasiatic Languages and Linguistics, 1, 41-74. https://doi.org/10.1163/187666309X12491131130701

Kiparsky, P. (2003). Syllables and moras in Arabic. In F. Caroline, \& R. Van de Vijver (Eds.), The optimal syllable (pp. 47-182). Cambridge, England: Cambridge University Press. https://doi.org/10.1017/CBO9780511497926.007

Kurdi, M. Z. (2016). Natural language processing and computational linguistics1: Speech, morphology and syntax. New Jersey, US: John Wiley \& Sons. https://doi.org/10.1002/9781119145554

Lahrouchi, M. (2018). Syllable structure and vowel/zero alternations in Moroccan Arabic and Berber. In A. Agwele, \& A. Bodomo (Eds.), The routledge handbook of African linguistics (pp.168-180). New York, NY: Routledge Taylor \& Francis Group. https://doi.org/10.4324/9781315392981-9

Louriz, N. (2004). Repair strategies in loanword phonology. Essex Graduate Student Papers in Language and Linguistics, 6, 153-167.

Lucas, C. (1995). Sociolinguistics in deaf communities. Washington: Gallaudet University Press.

Mahadin, R. S. (1982). The morphophonemics of the standard Arabic triconsonantal verbs. Ph.D. Dissertation, Philadelphia University, Pennsylvania, US.

Mangiro, R. A. (2016). The morphology of loanwords in Urdu: The Parsian, Arabic and English strands. UK: Cambridge scholars publishing. 


\section{Macrothink}

International Journal of Linguistics

ISSN 1948-5425

2020, Vol. 12, No. 2

McCarthy, J. (2002). A thematic guide to optimality theory. Cambridge, England: Cambridge University Press. https://doi.org/10.1017/CBO9780511613333

McCarthy, J. (2007). What is optimality theory. Linguistics Department Faculty Publication Series, 93, 1-28. https://doi.org/10.1111/j.1749-818X.2007.00018.x

McCarthy, J. (2008). Doing optimality theory: Applying theory to data. Oxford, UJ: Blackwell publishing. https://doi.org/10.1002/9781444301182

Orie, O. O. (2014). Theories of Nasal Vowel Representation and Nasal Vowel Asymmetries in Yoruba Borrowings. Tulane University Working Papers No. 1. 43-60. Tulan University: Fleur de Ling.

Orie, O. O. (2018). Yoruba Loans and Two Theories of Nasal Vowels. In O. Adesola, A. Akinlabi, \& O. Orie (Eds.), Data-rich linguistics: Papers in honor of Yiwola Awoyale (pp. 187-209). Newcastle, UK: Lady Stephenson Library.

Paradis, C. (1996). The inadequacy of filters and faithfulness in loanword adaptation. In D. Jacques, \& L. Bernard (Eds.), Current trends in phonology. Salford: University of Salford Publications.

Paradis, C., \& Lacharité, D. (1997). Preservation and minimality in loanword adaptation. $J$. Linguistics, 33, 379-430. https://doi.org/10.1017/S0022226797006786

Rose, Y. (1999). A structural account of root node deletion in loanword phonology. Canadian Journal of Linguistics, 44, 359-404. https://doi.org/10.1017/S0008413100017473

Rungruang, A. (2007). English Loanwords in Thai and Optimality Theory. Unpublished Ph. D. Dissertation, Naresuan University Phisanulok, Thailand.

Sayahi, L. (2005). Phonological adaptation of Spanish loanwords in Northern Moroccan Arabic. Penn Working Papers in Linguistics, 2(1), 253-262.

Uffmann, C. (2006). Vowel epenthesis in loanword phonology. Unpublished Ph. D. Dissertation, Marburg University, Marburg, Germany. https://doi.org/10.1515/9783110934823

Viola, M. (2005). Markedness and faithfulness in vowel systems. New York: Routledge.

Wornyo, A. A. (2016). English loanwords in Ewe: A phonological analysis. Journal of Literature, Languages and Linguistics, 22.

Yip, M. (1993). Cantonese loanword phonology and optimality theory. Journal of East Asian Linguistics, 2(3), 261-291. https://doi.org/10.1007/BF01739135

\section{Copyrights}

Copyright for this article is retained by the author(s), with first publication rights granted to the journal.

This is an open-access article distributed under the terms and conditions of the Creative Commons Attribution license (http://creativecommons.org/licenses/by/4.0/) 